\title{
RIGLYNE VIR DIE KLINIESE BEGELEIDING VAN STUDENTVERPLEEGKUNDIGES DEUR DIE KLINIESE BEGELEIDSPAN
}

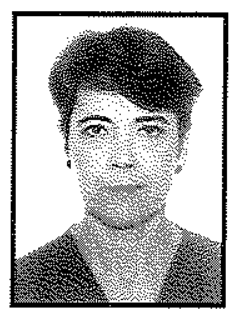

Engela du Plessis

M.A. Verpleegkunde, Lektor, Skool vir Verpleegkunde,

Potchefstroom Universiteit vir Christelike Hoër Onderwys

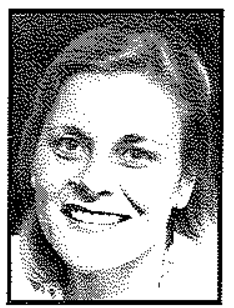

\section{Minrie Greeff}

D.Cur. Psigiatriese Verpleegkunde, Professor en Direkteur, Skool vir Verpleegkunde, Potcheftroomse Universiteit vir Christelike Hoër Onderwys

\begin{abstract}
In a previous article titled: "Die belewenis van die kliniese begeleidingspan van hul betrokkenheid by die kliniese begeleiding van studentverpleegkundiges" an overview was given of the problem statement, objectives, research design, research methodology, results and recommendations of this research. It was found that the involvement of the members of the clinical accompaniment team varied, with a disturbance in the partnership relationship, so that clinical accompaniment did not come fully into its own.
\end{abstract}

The focus of this article is on the specific guidelines formulated from the research findings and literature. These guidelines were formulated in respect of the implementation of the clinical accompaniment process, effective interpersonal relations, in-service training in teaching-learning principles and the expansion of the lecturer's skills in practice.

The authors believe that the implementation of the guidelines could possibly lead to a partnership relationship in the clinical accompaniment team, which could enhance involvement in clinical accompaniment and could thus lead to the facilitation of the student nurse's quest to become an independent professional practitioner who renders high quality nursing.

\section{OPSOMMING}

In 'n vorige artikel getiteld: "Kliniese begeleiding van studentverpleegkundiges deur die kliniese begeleidingspan", is 'n oorsig van die probleemstelling, doelwitte, navorsingsontwerp en-metode, resultate en aanbevelings van hierdie navorsing verskaf. In die navorsing is bevind dat die betrokkenheid van die lede van die kliniese begeleidingspan wissel, met' $n$ versteuring in die vennootskapsverhouding, met die gevolg dat kliniese begeleiding nie tot sy volle reg kom nie.

Die fokus van hierdie artikel is op die spesifieke riglyne wat vanuit die navorsingsbevindinge en literatuur geformuleer is. Dié riglyne is geformuleer met betrekking tot die implementering van die kliniese begeleidingsproses, effektiewe interpersoonlike verhoudinge, indiensopleiding in die onderrigleerbeginsels en uitbreiding van die dosent se praktykvaardigheid.

Die outeurs is van mening dat die implementering van die riglyne moontlik kan lei tot ' $n$ vennootskapsverhouding in die kliniese begeleidingspan, wat betrokkenheid by kliniese begeleiding kan bevorder en sodoende kan lei tot die fasilitering van die studentverpleegkundige se strewe om 'n selfstandige professionele praktisyn te word wat hoë gehalte verpleging lewer. 


\section{INLEIDING EN PROBLEEMSTELLING}

Die kuns en wetenskap van verpleging word deur die studentverpleegkundige bemeester deur teoretiese en kliniese onderrig, aldan gestruktureerde kliniese onderrig en kliniese begeleiding. Laasgenoemde impliseer die noodsaaklike deel van die opleidingsprogram wat " ...die doelbewuste, doelgerigte, stelselmatige leiding van die een wat opgelei word om hom of haar in staat te stel om volle verantwoordelikheid vir onafhanklike optrede te aanvaar", is (Mellish, 1983:4).

Die debat oor wie verantwoordelikheid vir kliniese begeleiding van die studentverpleegkundige moet aanvaar word reeds baie jare en deur verskeie outeurs gevoer (vergelyk onder meer Muller, 1989:21-25; Van Niekerk, 1989:16-18; Kirkpatrick et al. 1991:102-105; Acton et al. 1992:38-41; Bezuidenhout \& Basson, 1992:27; Gross et al. 1993:156-159).

Verskeie verpleegkundiges word in die kliniese begeleiding van die studentverpleegkundige geimpliseer, naamlik die eenheidsverpleegkundige, die dosent en kliniese dosent en elkeen se betrokkenheid het deur die jare verskil. Goodchild-Brown (1986:5) maak melding van 'n kliniese begeleidingspan, wat uit 'n kliniese dosent, eenheidsverpleegkundige en sone-matrone (toesighouer) bestaan, met die dosent as bronpersoon. Ander outeurs is meer ten gunste daarvan dat die dosent teoretiese sowel as kliniese onderrig moet waarneem (Paverd, 1985:9-12; Alberts, 1990:19; Van Niekerk, 1993:86).

As dosente en kliniese begeleiers van studentverpleegkundiges in drie hospitale in die Wesvaalstreek van die Noordwesprovinsie, is dit die outeurs se subjektiewe ervaring dat die gesindheid met betrekking tot kliniese begeleiding deur eenheidsverpleegkundiges in die algemene sale waar studentverpleegkundiges praktykervaring opdoen, dié is van onbetrokkenheid en dat dosente verskillende benaderings het ten opsigte van die kliniese begeleidingsproses. 'n Verdere waarneming is dat die volle geïdentifiseerde kliniese begeleidingspan, bestaande uit die eenheidsverpleegkundige, dosent en kliniese dosent, nie tans in hierdie hospitale as sodanig funksioneer nie.

Die verantwoordelikheid vir die kliniese begeleiding berus dus hoofsaaklik by die kollege- of die universiteitsdosent wat funksioneer binne 'n dosent-studentratio van ongeveer 1:21. Uit die voorafgaande het die vraag dus ontstaan wat die lede van die kliniese begeleidingspan se belewenis van hul betrokkenheid by kliniese begeleiding van die studentverpleegkundige is, asook hoe die lede van die span sinvol betrek kan word sodat elkeen sy regmatige verantwoordelikheid neem vir die kliniese begeleiding van studentverpleegkundiges. Die navorsing het dus ten doel gehad om: (i) ondersoek in te stel na die belewenis van alle lede van die kliniese begeleidingspan van hul eie en die ander lede se betrokkenheid by kliniese begeleiding van studentverpleegkundiges, en (ii) aan die hand van die bevindinge, riglyne te stel waardeur alle lede van die kliniese begeleidingspan betrokke sal wees by die kliniese begeleiding van die studentverpleegkundige, sodat die strewe van die studentverpleegkundige om 'n selfstandige professionele praktisyn te word wat hoë gehalte verpleging lewer, deur die kliniese begeleiers gefasiliteer word.

\section{METODE}

'n Kwalitatiewe studie is binne die konteks van drie hospitale en twee opleidingsinstansies in die Noordwes Provinsie geloods. Twee populasies is ingesluit, naamlik:

Populasie 1 behels die eenheidsverpleegkundiges wat werk in die algemene sale van twee hospitale in die Wesvaalstreek van die Noordwesprovinsie, waar studentverpleegkundiges praktykervaring opdoen.

Populasie 2 behels die dosente van die betrokke universiteit en dosente en kliniese dosente van die verplegingskollege in die Wesvalstreek van die Noordwesprovinsie, wat Algemene Verpleegkunde doseer en/of kliniese begeleiding van studentverpleegkundiges in die algemene praktykarea waarneem.

'n Doelgerigte vrywillige steekproef is gebruik waar die deelnemers volgens spesifieke kriteria geselekteer is, waaruit drie gerealiseer het om fokusgroepe vir die insameling van die data te vorm. Twee fokusgroepe was saamgestel uit eenheidsverpleegkundiges vanuit die hospitale en een fokusgroep uit dosente van die universiteit asook dosente en kliniese dosente van die verplegingskollege. Die fokusgroepe is gefasiliteer deur 'n enkele ongestruktureerde fenomenologiese vraag te vra met betrekking tot die deelnemers se belewenis van hul eie en die ander lede se betrokkenheid by kliniese 
begeleiding van studentverpleegkundiges.

Die verbatim transkripsies van die fokusgroepe is deur middel van inhoudsanalise geanaliseer en 'n literatuurkontrole is gedoen waardeur die resultate aan die hand van bestaande literatuur en navorsing gekontroleer is. Vervolgens is die riglyne vir die kliniese begeleiding van die studentverpleegkundige deur die kliniese begeleidingspan aan die hand van die navorsingsresultate en die literatuurkontrole geformuleer.

\section{RIGLYNE VIR DIE KLINIESE BEGELEIDING VAN STUDENT - VERPLEEGKUNDIGES DEUR DIE KLINIESE BEGELEIDINGSPAN}

Dit blyk uit hierdie navorsing dat die onvoldoende betrokkenheid van die kliniese begeleidingspan by die kliniese begeleiding van studentverpleegkundiges wentel om faktore soos oneffektiewe interpersoonlike verhoudinge tussen die lede van die kliniese begeleidingspan, onkunde oor onderrig-leerbeginsels en die kliniese begeleidingsproses, dosente se ontoereikende praktykervaring, asook 'n gebrek aan skakeling tussen die lede van die kliniese begeleidingspan. Die gebrek aan skakeling tussen die kliniese begeleiers is waarskynlik die indirekte oorsaak van die ander bogenoemde faktore wat voldoende betrokkenheid van die kliniese begeleidingspan belemmer.

Die riglyne wat geformuleer is het dus ten doel om die volle kliniese begeleidingspan te betrek by die kliniese begeleiding van die studentverpleegkundige vir die fasilitering van haar strewe om 'n selfstandige professionele praktisyn te word wat hoë gehalte verpleging lewer.

Aangesien die fokus van hierdie navorsing op die kliniese begeleidingsproses sowel as die vennootskapsverhouding tussen die lede van die kliniese begeleidingspan is, word die riglyne geformuleer met betrekking tot die volgende aspekte:

- Die toepassing van die kliniese

begeleidingsproses.

- Die fasilitering van effektiewe interpersoonlike verhoudings tussen die lede van die kliniese begeleidingspan.

- Die ontwikkeling van 'n vennootskapsverhouding in die kliniese begeleidingspan.

- Effektiewe interaksie tussen die lede van die kliniese begeleidingspan, sowel as tussen die onderrig-en verpleegdiensinstansies.

- Verbetering van kommunikasievaardighede.

- Uitbreiding van dosente se kliniese praktykvaardighede.

- Uitbreiding van die lede van die kliniese begeleidingspan se kennis van die onderrigleerproses.

\section{Riglyne vir die toepassing van die kliniese begeleidingsproses}

Hierdie riglyne word aan die hand van die wetenskaplike metode van verpleging gestel, volgens die beskrywings van Carpenito en Duespoh1 (1985:14-24, 90-165), Alberts (1990:20-22), Reilly en Oermann (1985:252-24) en White en Ewan (1991:118-188). Die onderskeie fases word nie as losstaande eenhede beskou nie maar loop ineen soos 'n spiraal, waar die evalueringsfase weer ineenloop met die beramingsfase.

- Dit sou sinvol wees vir die dosent wat volgens Myrick en Barrett (1994:196) verantwoordelik is vir "providing the crucial communication link between the educational and practice settings", om as koördineerder tydens die kliniese begeleidingsproses op te tree. Ten einde ' $n$ sinvolle vennootskapsverhouding in die kliniese begeleidingspan te vestig, skakel die dosent eerstens met die leier van die verpleegdiensinstansie, naamlik die verpleegdiensbestuurder. Sodoende kan suksesvolle skakeling en samewerking tussen al die lede van die kliniese begeleiding- span verseker word.

\section{Die beramingsfase in die kliniese begeleidings- proses}

- Die beramingsfase word gesamentlik deur die lede van die kliniese begeleidingspan aangepak met die doel om ' $n$ sinvolle beplanning van kliniese begeleiding te koördineer. Die beramingsfase volg direk op die evalueringsfase wat teen die einde van elke jaar plaasvind.

- Die dosente wat verantwoordelik is vir die konsepkurrikulum in Algemene Verpleegkunde bepaal die vakinhoud wat noodsaaklik is vir die lewering van hoe gehalte verpleging binne die gesondheidsdiensleweringstelsel. Hulle verseker dat die vakinhoud toepaslik is vir die tyd, provinsie en die mens wat verpleeg word. Hierdie 
beraming ten opsigte van die vakinhoud sal verseker dat die kurrikulum hanteerbaar is in verhouding tot die beskikbare tyd vir teoretiese onderrig en praktykervaring. Sodoende word die studentverpleegkundige se opleidingsprogram nie oorlaai nie.

- Die dosente en eenheidsverpleegkundiges maak vervolgens 'n opname van die tipe pasiënte (mediese en chirurgiese toestande), asook meegaande verpleegtake wat in elke eenheid in die praktykarea voorkom.

- Die dosente en eenheidsverpleegkundiges beraam gesamentlik die onderrigleerklimaat in elke eenheid. Skenk hier oorweging aan:

- die gehalte verpleging wat in die eenheid gelewer word;

- die filosofie van die eenheid met betrekking tot verpleegdiens en verpleegonderrig; die indiensopleidingsprogram in die eenheid;

- voorraad en fasiliteite wat in die eenheid beskikbaar is;

- fisiese hulpbronne vir onderrig en leer, soos prosedurehandleidings, praktykonderriggidse, en evalueringsinstrumente;

- onderrigvaardigheid (wat ook evalueringsvaardigheid insluit) van eenheidsverpleegkundiges; en

- die houding van eenheidsverpleegkundiges teenoor kliniese begeleiding van studentverpleegkundiges (Quinn, 1988:404).

- Die kliniese begeleiers beraam die bestaande kennis en vaardigheid wat elke studentverpleegkundige in die praktykarea bereik het, aan die hand van vorderingsverslae en kliniese evalueringsverslae.

- Die leerbehoeftes van elke studentverpleegkundige word vervolgens op grond van haar bestaande vlak van kennis en vaardigheid, asook op grond van die vereiste onderrigdoelwitte beraam. Nadat die kliniese begeleiers dié beraming gedoen het, word die studentverpleegkundige betrek om haar insette te lewer ten opsigte van haar individuele leerbehoeftes.

- Die kliniese begeleiers beraam gesamentlik die aantal studentverpleegkundiges wat gedurende bepaalde periodes in die eenhede sal wees vir praktykervaring, ten einde die verhouding van kliniese begeleiers tot studentverpleegkundiges in elke eenheid te bepaal.

\section{Die beplanningsfase in die kliniese begeleidingsproses}

- Die dosente lê die konsepkurrikulum wat as fisiese hulpbron in die opleiding van student-verpleegkundiges dien, aan die eenheids-verpleegkundiges in die algemene praktyk-area voor, met die doel dat die eenheids- verpleegkundiges insette lewer, ten einde te verseker dat die kurrikulum voldoen aan die werklikheidseise van die praktykarea (Van Niekerk, 1993:130, 131).

- Die dosente wat betrokke is by die onderrig van die onderskeie jaargroepe in Algemene Verpleegkunde stel na die afhandeling van die kurrikulering, onderrigdoelwitte vir studentverpleegkundiges van elke jaargroep. Hierdie doelwitte word aan die hand van die einddoelstelling in die kurrikulum gestel en volg progressief van eenvoudige na meer ingewikkelde doelstellings. Die dosente van die universiteit en die verplegingskollege kan die onderrigdoelwitte hierna vergelyk, om te verhoed dat twee verskillende stelle doelwitte vir studentverpleegkundiges wat op dieselfde vlak van opleiding is, gestel word.

- Die dosente bepaal vervolgens die vakinhoud aan die hand van die onderrigdoelwitte. Dit kan sinvol wees om dié vakinhoud in logiese eenhede wat, soos die onderrigdoelwitte, progressief op mekaar volg, in te deel.

- Die dosent wat as koördineerder van die kliniese begeleidingspan optree, kan in hierdie stadium van beplanning ' $n$ werkswinkel organiseer, ten einde die insette van al die lede van die kliniese begeleidingspan te koördineer. Die beplanning van die werkswinkel moet in samewerking met die verpleegdiensbestuurders van die betrokke hospitale gedoen word om soveel as moontlik eenheidsverpleegkundiges (maar ten minste een van elke eenheid) te betrek. Die tye en die plek van die werkswinkel moet só beplan word dat al die lede van die kliniese begeleidingspan wat van die aanvang van die werkswinkel af betrokke is, deurgaans betrokke kan bly tot die doel van die werkswinkel bereik is.

Die insette van al die lede van die kliniese begeleidingspan wat tydens die werkswinkel gelewer word, kan moontlik oorvleueling van kliniese begeleidingsdoelwitte uitskakel.

Hierdie wyse van skakeling tydens die beplanning van die kliniese begeleidingsprogram kan bydra om die teorie-praktykgaping te oorbrug (Brereton, 


\section{5:321).}

Die resultate van die werkswinkel kan aan die eenheidsverpleegkundiges wat nie hieraan kon deelneem nie voorgelê word vir bevestiging en uitbreiding. Dit sou sinvol wees indien hulle dan ook by die individuele vergaderings in die eenhede (vgl. 'n volgende riglyn), waartydens leergeleenthede in die spesifieke eenhede geïdentifiseer word, betrek word.

- Onderrigmetodes en leergeleenthede vir die teorie sowel as die praktyk word vervolgens, tydens die werkswinkel, aan die hand van die onderrigdoelwitte, beplan. Dit sou sinvol wees om die teoretiese en kliniese leergeleenthede gelyktydig te beplan. Sodoende kan elke leergeleentheid as 'n holistiese fenomeen benader word in 'n poging om in die onderrigdoelwitte te slaag.

- Dit sou sinvol wees om tydens die werkswinkel ook evalueringsmetodes en spertye vir die bereiking van elke doelwit te beplan.

- Dit kan oorweeg word om leergeleenthede wat sonder direkte begeleiding van 'n kliniese begeleier benut kan word, te onderskei deur dit met ' $n$ asterisk (*) op die program aan te dui. Leergeleenthede wat met portuurgroepbegeleiding benut kan word kan ook met ' $n$ (p) op die program aangedui word.

- Die leergeleenthede in die praktykarea waar die studentverpleegkundige deur die eenheidsverpleegkundige begelei word, word só beplan dat dit ingeskakel word by die daaglikse verpleegtake. Sodoende word die eenheidsverpleegkundige se las in die eenheid nie verder deur kliniese begeleiding as 'n bykomende taak verswaar nie.

- Die dosente koördineer eenheidsvergaderings, waartydens die kliniese begeleiers in die onderskeie eenhede toepaslike leergeleenthede wat in dié eenheid benut kan word, aan die hand van die kliniese begeleidingsprogram beplan. Leergeleenthede word egter ook op 'n deurlopende basis, as onderrigmomente, deur die kliniese begeleiers en deur die studentverpleegkundiges geïdentifiseer en benut.

- Skenk oorweging daaraan om hierdie kliniese begeleidingsprogram in 'n studiegids en praktikaregister in te sluit, wat dan tesame met die kurrikulum in elke eenheid beskikbaar is as verwysingsbron tydens kliniese begeleiding (Bekker, 1989:181,182; Paverd, 1985:19). 'n Studiegids en praktikaregister bly ook in besit van die studentverpleegkundige as hulpbron vir selfgerigte leer.

- Dit sou sinvol wees om die studentverpleegkundige se plasing vir praktykervaring in die onderskeie eenhede aan die hand van die onderrigdoelwitte en praktykleergeleenthede, soos in die kliniese begeleidingsprogram, te beplan.

- Die dosent aanvaar verantwoordelikheid vir die beplanning van die plasing van studentverpleegkundiges in die praktykarea, hoewel dit in samewerking met al die lede van die kliniese begeleidingspan gedoen word, ten einde die teorie-praktykgaping uit te skakel (Reilly \& Oermann, 1985:96; Brereton, 1995:322; Piscopo, 1994:114).

- Die beplanning van die plasing van die studentverpleegkundige word ook aan die betrokke verpleegdiensbestuurders voorgelê ten einde ook hulle insette te kry sodat die diensbehoeftes van die hospitaal wel in ag geneem word sover as wat dit moontlik is, sonder dat die studentverpleegkundiges as die werkmag in die algemene praktykarea beskou word.

- Die dosent bied tydens die beplanning van elke individuele studentverpleegkundige se plasing in die praktykarea ook aan die studentverpleegkundige geleentheid om insette met betrekking tot haar plasing te lewer.

Sodoende kan die individuele leerbehoeftes van die studentverpleegkundige in ag geneem word, ter wille van die volle benutting van leergeleenthede.

- Die dosent lê die beplanning van die jaar se plasing aan elke eenheid se eenheidsverpleegkundiges voor sodat hulle ook insette kan lewer ten opsigte van: (i) die spesifieke tyd van plasing in die betrokke eenheid en (ii) die hanteerbare getal studentverpleegkundiges vir die spesifieke eenheid. Dit sou ook sinvol wees vir die dosent om by hierdie geleentheid 'n program met die spesifieke dienstye van die studentverpleegkundiges aan die eenheidsverpleegkundiges beskikbaar te stel. Dit kan haar in staat stel om die spesifieke toewysing van studentverpleegkundiges aan pasiënte te beplan.

- Skenk oorweging daaraan om studentverpleegkundiges slegs in eenhede waar 'n ondersteunende onderrig-leerklimaat heers te plaas. Wanneer groot getalle studentverpleegkundiges gelyktydig in die algemene praktykarea geplaas móét word, kan die dosent ander algemene praktykareas in die 
gemeenskap, buiten die hospitale, ondersoek om te bepaal of dit geskik sou wees vir plasing van studentverpleegkundiges (SARV, 1994:8; Reilly \& Oermann, 1985:86,87).

\section{Die implementeringsfase in die kliniese begeleidingsproses}

- Die dosent wat verantwoordelik is vir die onderrig van 'n spesifieke jaargroep studentverpleegkundiges oriënteer hulle in groepverband ten opsigte van: (i) die kliniese begeleidingsprogram, (ii) haar/sy (dosent) beplande begeleidingsaktiwiteite en (iii) beskikbaarheid van die dosent, met ander woorde waar die studentverpleegkundige haar/sy kan kontak indien sy/hy leiding nodig het.

- 'n Eenheidsverpleegkundige in elke eenheid oriënteer die studentverpleegkundiges ten opsigte van (i) die roetine in die eenheid, (ii) leergeleenthede in die eenheid en (iii) die beskikbaarheid van kliniese begeleiers in die eenheid, sodat die studentverpleegkundige weet waar om enige tyd ' $n$ kliniese begeleier in die eenheid te kontak.

- Ten einde die studentverpleegkundige te ondersteun tydens kliniese begeleiding, gaan die kliniese begeleier met haar/hom 'n kontrak aan, wat aan haar/hom sekuriteit in die kliniese begeleidingsituasie bied. Dié kontrak handel oor (i) elke persoon in die kliniese begleidingsituasie se rol, (ii) elke persoon se verwagtinge en (iii) die terugvoering wat elkeen verwag.

- Ondersteun die studentverpleegkundige verbaal deur aanprysing wanneer sy/hy na verwagting presteer, asook deur aanmoediging wanneer sy/hy sukkel om 'n doelwit te bereik.

- Ondersteun die studentverpleegkundige nieverbaal deur gesigsuitdrukking, oogkontak, gebare en houding, wat goedkeuring of aanmoediging aandui.

- Ondersteun die studentverpleegkundige deur bloot teenwoordig te wees waar die studentverpleegkundige werk of 'n spesifieke vaardigheid inoefen, tot sy aandui dat die kliniese begeleier se teenwoordigheid nie meer benodig word nie.

- Die volgende fasette van waarneming van die studentverpleegkundige in die proses van kliniese begeleiding kan oorweeg word:

- Observeer die studentverpleegkundige se verpleeginteraksie waar sy besig is, sonder enige intrede en gee later terugvoer.

- Die studentverpleegkundige en kliniese begeleier kom ooreen dat die begeleier tydens 'n potensieel moeilike situasie bystaan en indien nodig, intree op ' $n$ wyse wat vir beide die studentverpleegkundige en die pasiënt aanvaarbaar is

- Fokus op die pasiënt om waar te neem of die studentverpleegkundige se beraming van die pasiënt korrek is en ondersteun die studentverpleegkundige toepaslik in die spesifieke situasie.

- Die kliniese begeleier fokus op haar/sy eie optrede as begeleier en vra terugvoer van die studentverpleegkundige sowel as van die pasiënt oor die effektiwiteit van die begeleiding.

- Oorweeg die volgende leidinggewende interaksies, wat noodsaaklik is vir die fasilitering van die studentverpleegkundige se strewe na selfstandigheid in die praktyk:

- Gee leiding aan die selfgerigte studentverpleegkundige wat reeds ' $n$ bepaalde vaardigheidsvlak bereik het, maar in 'n spesifieke situasie onseker is.

- Gee leiding aan die studentverpleegkundige om tydens die uitvoer van 'n prosedure, buigbaar te wees ten opsigte van tegniese aspekte, asook om die totaliteitskonsep en probleemoplossing tydens verpleeginteraksies te integreer.

- Gee leiding om vaardigheid te bereik, konsepte toe te pas en probeemoplossend te verpleeg.

- Gee terugvoer aan die studentverpleegkundige oor 'n spesifieke verpleegtaak waarop ooreengekom is, asook oor haar verpleegvaardigheid in die algemeen.

- Fasiliteer die studentverpleegkundige in haar strewe na'n selfstandige professionele praktisyn wat hoë gehalte verpleging lewer deur andragogiese onderrig-leerbeginsels toe te pas, asook deur effektiewe interpersoonlike verhoudinge te vestig.

- Dit sou sinvol wees om na afloop van 'n kliniese begeleidingsessie (na 'n dag of 'n week, soos toepaslik), 'n terugvoersessie te koördineer waartydens studentverpleegkundiges geleentheid gegee word om te reflekteer oor hul leerervaringe. Hierdie terugvoersessies kan op ' $\mathrm{n}$ individuele basis of in 'n klein groepie geskied, waar reflektering en probleemoplossing gekombineer word.

\section{Die evalueringsfase in die kliniese begeleidingsproses}

Die studentverpleegkundige sowel as die kliniese 
begeleidingspan word tydens dié fase by evaluering betrek. Vervolgens die riglyne vir hierdie evaluering:

- Evalueer die studentverpleegkundige in die kliniese begeleidingsituasie om te bepaal of haar/sy kennis en vaardigheid op die vereiste standaard is, asook om spesifieke interaksies van die studentverpleegkundige aan te moedig of te ontmoedig.

- Ondersteun die studentverpleegkundige sodat dit vir haar/hom moontlik is om te leer uit foute wat sy/hy begaan het.

- Die kliniese begeleiers stel gesamentlik evalueringsinstrumente aan die hand van die onderrigdoelwitte op om sodoende te verseker dat elke studentverpleegkundige regverdig geëvalueer word.

- Evalueer die studentvepleegkundige volgens die kriteria in die evalueringsinstrumente en volgens die evalueringsmetodes wat op grond van onderrigdoelwitte geselekteer is.

- Gebruik vormende en eindevaluering. Vormende evaluering word gebruik om die vordering van die studentverpleegkundige te monitor en deurlopend aan haar/hom terugvoer te gee ten opsigte van haar vordering. Eindevaluering word gebruik om na voltooing van' $n$ kursuseenheid te bepaal of die studentverpleegkundige die voorafbepaalde doelwitte volgens die verwagte standaard bereik het. Dokumenteer die vormende evaluering van elke studentverpleegkundige sodat sy/hy ook self haar/sy vordering kan monitor en die ander kliniese begeleiers op hoogte kan wees met elke studentverpleegkundige se vordering.

- Gee na afloop van elke kursuseenheid aan die studentverpleegkundiges geleentheid om die kliniese begeleiding wat sy/hy ontvang het te evalueer en terugvoer te gee ten opsigte van die:

- beskikbaarheid van die kliniese begeleiers;

- kliniese praktykvaardigheid van die kliniese begeleiers;

- die standaard wat die kliniese begeleiers stel; en

- konsekwentheid van die kliniese begeleiding.

- Die kliniese begeleidingspan belê maandeliks 'n kort eenheidsvergadering met die doel om aan mekaar terugvoer te gee ten opsigte van die effektiwiteit van hul kliniese begeleiding (Atkins \& Williams, 1995:1012).

- Die kliniese begeleidingspan evalueer die kliniese begeleidingsproses op 'n deurlopende basis en gee tydens die maandelikse eenheids vergaderings terugvoer of die kliniese begeleidingsdoelwitte bereik is en of

leergeleenthede in die eenheid ten volle benut is.

- Die lede van die kliniese begeleidingspan kan beplan om soms 'n studentverpleegkundige gesamentlik te begelei en dan na afloop van dié begeleidingsessie, aan mekaar terugvoer te gee ten opsigte van elkeen se begeleidingsinteraksies.

- Dit sou sinvol wees om elke eenheidsvergadering te notuleer, asook om die evaluering deur die studentverpleegkundiges te dokumenteer ten einde in staat te wees om die effektiwiteit van die kliniese begeleidingsproses te monitor.

- Die volledige kliniese begeleidingsprogram word teen die einde van die kurrikuleringsiklus (normaalweg driejaarliks) geëvalueer en hersien ten einde in pas te bly met veranderende verpleegopleidings- en verpleegdienseise, asook met veranderende eise van die gemeenskap.

\section{Riglyne vir interpersoonlike verhoudinge in die kliniese begeleidingsituasie}

Effektiewe interpersoonlike verhoudinge is gebaseer op interpersoonlike vaardighede wat volgens Wilson-Barnett et al. (1995:1153) noodsaaklik is vir effektiewe kliniese begeleiding. Riglyne word vervolgens aan die hand van vier komponente van interpersoonlike vaardighede, naamlik (i) kennis van en vertroue in mekaar, (ii) akkurate en ondubbelsinnige kommunikasie, (iii) wedersydse vertroue en ondersteuning en (iv) konflikhantering en probleemoplossing in verhoudings, gestel (Johnson, 1981:6,7).

- Die dosent, wat as koördineerder van die

kliniese begeleidingspan optree, kan met die

toestemming van die kliniese begeleidingspan, 'n persoon wat kundig is op die gebied van interpersoonlike vaardighede nader om kursusse vir die lede van die kliniese begeleidingspan aan te bied.

Die dosent skakel dan met die res van die lede van die kliniese begeleidingspan, asook met die verpleegdiensbestuurders van die hospitale, die prinsipaal van die verplegingskollege en die departementshoof van die Departement Verpleegkunde van die universiteit ten einde die interpersoonlike vaardigheidskursusse te koördineer vir dié lede van die kliniese begeleidingspan wat nie onlangs so 'n kursus gedoen het nie. 
Dit sou sinvol wees om die kursus in eenhede, volgens die komponente van interpersoonlike vaardighede in te deel. Die verskillende eenhede kan dan tydens geskeduleerde sessies, in meer as een siklus, aangebied word. Elke lid van die kliniese begeleidingspan neem dan self verantwoordelikheid om al vier die eenhede by te woon wanneer dit haar/hom die beste pas.

- Die komponente en die vaardighede wat moontlik by elke eenheid ingesluit kan word is soos volg:

\section{Eenheid 1: Kennis van mekaar en vertroue in mekaar}

- Pas die volgende vaardighede in die kliniese begeleidingsituasie toe, ten einde mekaar te ken en te vertrou:

- Ken en aanvaar jouself om in staat te wees tot selfblootlegging aan die ander persoon in die vennootskapsverhouding.

- Wees toeganklik vir die ander persoon.

- Bou aan wedersydse vertroue, deur die risiko van selfblootlegging, wat moontlik aanvaarding as respons kan uitlok.

- Waak daarteen om wedersydse vertroue te skend, deur die ander persoon se self blootlegging met verwerping te beantwoord (Johnson, 1981:15-71).

\section{Eenheid 2: Kommunikasievaardighede}

- Oefen vaardighede van kommunikasie, wat gedefinieer word as: ". . a message sent by a person to a reciever(s) with the conscious intent of effecting the reciever's behaviour" (Johnson, 1981:74). Die vaardighede wat hier ter sprake is, is die volgende:

- Stuur effektiewe verbale en nie-verbale boodskappe.

- Luister met aandag na die boodskap wat versend word.

- Reageer toepaslik op die boodskappe wat versend is, met die volgende moontlike response:

(i) evaluerende respons

(ii) interpreterende respons

(iii) ondersteunende respons

(iv) ondersoekende (peilende) respons

(v) begrypende respons

- Aanvaar jouself ten einde in staat te wees om die ander persoon ook te aanvaar

(Johnson, 1981:73-169).

\section{Eenheid 3: Aanvaarding en ondersteuning van die ander persoon}

- Aanvaar jouselfen die ander in die vennootskapsverhouding ten einde sinvolle verhoudings met ander persone in die kliniese begeleidingsituasie op te bou en in stand te hou. Die vaardighede wat hiervoor nodig is, is soos volg:

- Poog om jouself te aanvaar deur gewilligheid om jou gedagtes, gevoelens en reaksies teenoor die ander persoon bloot te lê; te sorg vir jou psigologiese welsyn; en ander persone te aanvaar.

- Beskryf jou sterk punte wanneer dit toepaslik is.

- Spreek aanvaarding van die ander persoon uit wanneer dit toepaslik is (Johnson, 1981:171193).

\section{Eenheid 4: Koflikhantering en probleem- oplossing in verhoudings}

- Pas die volgende strategieë vir konflikhatering en probleemoplossing toe:

- Word bewus van jou eie konflikstyl.

- Definieer die konflik.

- Weet wanneer om te konfronteer.

- Definieer die konflik saam met die ander persoon in die situasie.

- Konflikdefiniëring volgens die saak en nie persoonlikhede nie.

- Bepaal die verskil tussen jou en die ander persoon.

- Beskou die konflik vanuit die ander persoon se gesigspunt.

- Verhoog jou eie en die ander party(e) se motivering om die konflik op te los.

- Hanteer jou eie gevoelens wat moontlik die konflik kan vererger.

- Bereik'n ooreenkoms vir die oplossing van en voorkoming van 'n herhaling van dié konflik.

- Vermy algemene wanpersepsies wat die konflik kan vererger (Johnson, 1981:195294).

Riglyne vir indiensopleiding van die kliniese begeleidingspan ten opsigte van andragogiese onderrig-leerbeginsels

Deur indiensopleiding word die kundigheid en vaardigheid van die lede van die kliniese begeleidingspan opgeknap en uitgebou, wat hul betrokkenheid by die kliniese begeleiding van studentverpleegkundiges behoort te bevorder (Van Niekerk, 1993:84).

- Dit kan sinvol wees om kliniese begeleidingsessies te beplan waartydens die eenheidsverpleegkundige wat onseker voel, die 
kliniese begeleiding van'n student-

verpleegkundige saam met 'n ervare dosent waarneem. Sodoende kan sy/hy deur observasie, praktiese ervaring opdoen van die toepassing van andragogiese onderrigleerbeginsels in die kliniese begeleidingsproses.

- Die dosent as koördineerder in die kliniese begeleidingspan lei die beplanning van die indiensopleiding vir kliniese begeleiding. Dit sou sinvol wees indien die kliniese begeleidingspan aan die begin van die jaar by dic mees sentrale punt, hetsy dic universiteit, verplegingskollege of 'n hospitaal vergader. Die doel van dié vergadering sou wees om: (i) 'n koördineerder van die indiensopleidingsprogram aan te wys, (ii) die voorlopige programinhoud vir indiensopleidin te bepaal en (iii) ' $n$ indeling van sones (twee of meer eenhede in die hospitaal) te maak en dan elke dosent toe te wys aan' 'n sone of meer. Die doel van só 'n toewysing is om die skakeling

Figuur 1: Voorgestelde skedule vir indiensopleidingsprogram

\begin{tabular}{|l|l|l|l|}
\hline PROGRAMINHOUD & TYD & PLEK & AANBIEDER \\
\hline leerders & & & \\
\hline $\begin{array}{l}\text { Eenheid 2: Aannames met betrekking tot leer en } \\
\text { onderrig }\end{array}$ & & & \\
\hline Eenheid 3: Faktore wat leer beïnvloed & & & \\
\hline Eenheid 4: Onderrigbeginsels & & & \\
\hline Eenheid 5: Effektiewe kommunikasiestyle & & & \\
\hline
\end{tabular}

ten opsigte van die indiensopleidingsprogram in die onderskeie eenhede waar te neem.

- Die individuele dosente gaan direk na hierdie beplanningsvergadering na die sone of eenheid wat aan haar/hom toegewys is om die voorlopige programinhoud aan die eenheidsverpleegkundige voor te lê en hul insette te kry met betrekking tot: (i) hul behoefte aan indiensopleiding ten opsigte van onderrigleerbeginsels, (ii) die prioriteite van hierdie behoeftes, (iii) kundigheid en vaardigheid wat hulle kan aanbied tydens indiensopleidingsessies en (iv) geskikte tye vir elke eenheid wat geskeduleer kan word in die in die indiensopleidingskedule (vgl. figuur 1).

- Ongeveer twee weke na die eerste beplanningsvergadering gee die dosente terugvoer oor die insette van die eenheidsverpleegkundiges. Tydens hierdie sessie word verpleegdiensbestuurders en hoofverpleegkundiges van die onderskeie sones ook uitgenooi na die finale beplanningsessie van die indiensopleidingsprogram sodat hulle ook insette kan lewer met betrekking tot: (i) die skedule van die indiensopleidingsprogram, (ii) hul eie kundigheid en vaardigheid wat hulle kan aanbied tydens indiensopleidingsessies en (iii) toesighouding oor die uitvoering van die indiensopleidingsprogram.

- Nadat die insette van al die lede van die kliniese begeleidingspan ondersoek is, word ' $n$ finale indiensopleidingsprogram, wat oor' $n$ periode van een of selfs twee jaar kan strek, afhangende van die omvang van die inhoud en die beskikbare tye, beplan.

- Die indiensopleidingsperiodes wat in elke eenheid (saal) beplan word, moet verkieslik op vasgestelde dae en tye plaasvind, moontlik tydens 'n oorvleueing van die eenheidsverpleegkundiges se skofte.

- Dit kan sinvol wees om die totale programinhoud ten opsigte van andragogiese onderrig-leerbeginsels in kliniese begeleiding, in eenhede te skeduleer. Elke lid van die 
kliniese begeleidingspan aanvaar verantwoordelikheid om die verskillende eenhede van die program te deurloop. Hierdie eenhede kan soos volg ingedeel word:

\section{Eenheid 1: Aannames oor die eienskappe van leerders:}

- Selfgerigte studentverpleegkundiges aanvaar verantwoordelikheid vir eie leer.

- Die studentverpleegkundige het reeds 'n reservoir van ervaring.

- Gereedheid om te leer is behoeftegerig.

- Oriëntasie tot leer is taak-en probleemgesentreerd.

- Motivering vir leer is intern (Knowles soos aangehaal deur Quinn, 1988:47).

\section{Eenheid 2: Aannames met betrekking tot leer en onderrig}

- Volwassenes het die vermoë om te leer.

- Leer is 'n interne proses van behoeftebevrediging en doelgerigtheid

- Andragogiese onderrig-leerbeginsels is noodsaaklik in die kliniese begeleiding van studentverpleegkundiges

\section{Eenheid 3: Faktore wat leer beïnvloed}

- Elke studentverpleegkundige is ' $n$ individu wat vir haar/sy eie leer verantwoordelik is en teen haar/sy eie tempo leer.

- Motivering wat gefasiliteer kan word deur: (i) die benutting van bestaande dryfvere soos belangstellings, behoeftes, ideale en houdings en (ii) die formulering van doelstellings.

- Die totaliteitsbeginsel waar 'n geheelbeeld van die leermateriaal deurlopend aan die studentverpleegkundige voorgehou word.

- Bevrediging as gevolg van doelbereiking en die wete dat leer plaasvind.

- Oefening van vaardighede en herhaling tot vaardighede bereik is.

- Die leer van nuwe kennis is gebaseer op bestaande kennis en ervaring.

- Die verwantskap tussen nuwe en bestaande kennis.

- Aktiewe deelname deur die studentverpleegkundige, wat fisiese aktiwiteit, aktiewe luister en aktiewe waarneming insluit (Mellish \& Brink, 1990:83-92).

\section{Eenheid 4: Onderrigbeginsels}

- Kennis van die studentverpleegkundige en inagneming van haar/sy leerbehoeftes.

- Koördinering van die tyd van onderrig en leer.

- Evaluering deur kliniese begeleiers asook deur die studentverpleegkundige self.

- Duidelik geformuleerde kliniese begeleidingsdoelstellings.

- Onderrigvaardighede kan deur kliniese begeleiers aangeleer word.

- Beheer van die onderrig-leeromgewing sodat die studentverpleegkundige toegang het tot fasiliteite en leergeleenthede.

- Effektiewe interpersoonlike verhoudinge tussen die kliniese begeleier en die studentverpleegkundige, wat effektiewe kommunikasiestyle insluit (Mellish \& Brink, 1990:95).

\section{Eenheid 5: Effektiewe kommunikasiestyle}

- Die verskillende egostate tydens kommunikasie.

- Hantering van die onderrig-leersituasie tydens kliniese begeleiding vanuit 'n volwasseneegostaat.

- Kommunikasie vanuit 'n volwassene-egostaat (Eric Berne soos aangehaal deur Wilson \& Knies1, 1992:143-145).

\section{Riglyne vir die uitbreiding van dosente se kliniese praktykvaardigheid}

Slegs 'n kliniese begeleier wat oor kundigheid sowel as ervaring van die algemene praktykarea beskik kan effektiewe kliniese begeleiding doen. Vir die dosent wat die kundige van die vakgebied Algemene Verpleegkunde is en die meeste van haar/sy tyd aan doseer en ander akademiese take spandeer, is dit egter moelik om ook in die praktykarea vaardig te bly.

Tydens die dosent se geskeduleerde kliniese begeleidingsperiodes kan sy en die eenheidsverpleegkundige wat die kliniese ekspert is, gesamentlik kliniese begeleiding doen.Die kundigheid en ervaring van die dosent en eenheidsverpleegkundige dien dan wedersyds as leerervaring (Myrick \& Barrett, 1994:197; Brereton, 1995:322).

Dosente kan periodes in hul weeklikse werkprogram inpas waartydens hulle, onder supervisie van die eenheidsverpleegkundige as ekspert, in die algemene praktykarea werk.

Die indeling van haar/sy werkprogram kan dan soos volg daar uitsien (Hooper, 1987:61):

- $60 \%$ doseer-en ander verwante take,

- $20 \%$ kliniese onderrig en -begeleiding,

- $20 \%$ werk in die praktykarea onder supervisie van die eenheidsverpleegkundige asook 
ander indiensopleiding.

\section{SLOTSOM}

Uit hierdie navorsing blyk dit dat die betrokkenheid van die volle kliniese begeleidingspan by die kliniese begeleiding van die studentverpleegkundige noodsaaklik is vir die fasilitering van die studentverpleegkundige se strewe om 'n selfstandige professionele praktisyn te word wat hoë gehalte verpleging lewer. Die outeurs is van mening dat implementering van die riglyne wat voortgespruit het uit hierdie navorsing kan bydra tot' $n$ vennootskaps-verhouding tussen die lede van die span wat moontlik kan lei tot hierdie noodsaaklike betrokkenheid van die volle kliniese begeleiding-span.

"If nursing practitioners, researchers, teachers and managers really want to seek out what is best in nursing, they will have to do it together." (Alexander, 1989:992).

\section{VERWYSINGS}

ALBERTS, UU 1990: 'n Onderoek na die omvang van betrokkenheid van verpleegdosente in die kliniese onderrig by sekere opleidingsentra in Suid-Afrika. Pretoria: Universiteit van SuidAfrika.(Proefskrif-D.Lit.).

ALEXANDER, MF 1989: Nursing practitioners, researchers, teachers and managers all have the same goal: Editorial. Journal of Advanced Nursing, 14(12), Dec. 1989:991-992.

ATKINS, S \& WILLIAMS, A 1995: Registered nurse's experience of mentoring under-graduate nursing students. Journal of Advanced Nursing, 21(5), May 1995:1006-1015.

BEKKER, S 1989: Die invloed van die kliniese praktyk op die professionele sosialisering van die studentvepleegkundige. Johannesburg: Randse Afrikaanse Universiteit. (Verhandeling-M.Cur.)

BEZUIDENHOUT, MC \& BASSON, AA 1992: Die opleidingsfunksie van die geregistreerde verpleegkundige -deel 1. Curationis, 15(2), Jun. 1992:27-30.

BRERETON, ML 1995: Communication in nursing: the theory-practice relationship.

Journal of Advanced Nursing, 21(2), Feb. 1995:314-324.
CARPENITO, LJ \& DUESPOHL, TA 1985: A guide for effective clinical instruction; second edition. Rockville: Aspen.

GOODCHILD-BROWN, B 1986: Accompaniment of students by nurse teachers - a brief didactic study. Curationis, 9(2), 1986:5-9.

GROSS, JW; AYSSE, P \& TRACEY, P 1993: A creative clinical education model: three views. Nursing Outlook, 41(4), Ju1/Aug. 1993:156-159.

HOOPER, A 1987: In praise of decentralisation. Nursing Times, 83(41), Oct. 1987:660-62.

JOHNSON, DW 1981: Reaching out. Interpersonel effectiveness and self-actualization. Engelwood Cliffs: Prentice-Hall.

KIRKPATRICK, H; BYRNE, C; MARTIN, ML \& ROTH, ML 1991: A collaborative model for the clinical education of baccalaureate nursing students. Journal of Advanced Nursing, 16(1), Jan. 1991:101-107.

MELLISH, JM 1983: Eenheidsonderrig en administrasie vir verpleegkundiges. Durban: Butterworths.

MELLISH, JM \& BRINK, H 1990: Teaching the practice of nursing. A text in nursing didactics; third edition. Durban: Butterworths.

MULLER, M 1989: Die skep van 'n optimale leeromgewing. Nursing RSA Verpleging, 4(2), Feb. 1989:21-25.

MYRICK, F \& BARRETT, C 1994: Selecting clinical preceptors for basic baccalaureate nursing students: a critical issue in clinical teaching. Journal of Advanced Nursing, 19(1), Jan. 1994:194-198.

PAVERD, NV 1985: Ringing in the changes: the implications of the new regulations for the colleges. Curationis, 8(2), Jun. 1985:9-12.

PISCOPO, B 1994: Organizational climate, communication and role strain in clinical nursing faculty. Journal of Professional Nursing, 10(2), March/Apr. 1994:113-119.

QUINN, FM 1988: The principles and practice of nurse education; second edition. London: Croom Helm. 
REILLY, DE \& OERMANN, MH 1985: The clinical field. It's use in nursing education. Norwalk: Appleton-Century-Crofts.

SUID-AFRIKAANSE RAAD OP VERPLEGING 1994: Minimum vereistes vir die opleiding en gids betreffende die onderrig van studente in die program wat lei tot registrasie as 'n Verpleegkundige (Algemene, Psigiatriese en Gemeenskaps-) en Vroedvrou. Pretoria.

VAN NIEKERK, S 1989: Het sy tyd? Nursing RSA Verpleging, 4(4), Apr. 1989:16-18.

VAN NIEKERK, EC 1993: Riglyne vir teoriepraktyk korrelasie in die begeleiding van die studentverpleegkundige. Johannesburg: Randse Afrikaanse Universiteit. (Verhandeling-M.Cur.).

WHITE, R \& EWAN, C 1991: Clinical teaching in nursing. London: Chapman \& Hall.

WILSON, HS \& KNIESL, CR 1992: Psychiatric nursing. Redwood City: Addison Wesley.

WILSON-BARNETT, J; BUTTERWORTH, T; WHITE, E; TWINN, S; DAVIES, S \& RILEY, L 1995: Clinical support and the Project 2000 nursing student: factors influencing this process. Journal of Advanced Nursing, 21(6), Jun. 1995:1152-1158. 